ҚАЗАҚСТАН РЕСПУБЛИКАСЫ

ҰЛТТЫҚ ҒЫЛЫМ АКАДЕМИЯСЫНЫН

АБАЙ АТЫНДАҒЫ ҚАЗАҚ ҰЛТТЫҚ

ПЕДАГОГИКАЛЫҚ УНИВЕРСИТЕТІНІҢ

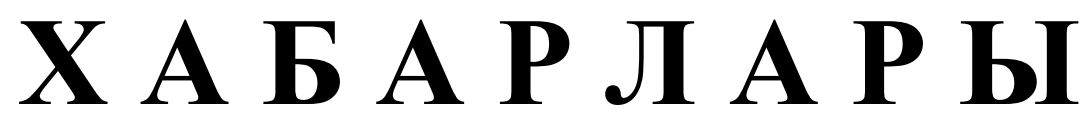

\section{ИЗВЕСТИЯ}

НАЦИОНАЛЬНОЙ АКАДЕМИИ НАУК РЕСПУБЛИКИ КАЗАХСТАН

КАЗАХСКИЙ НАЦИОНАЛЬНЫЙ

ПЕДАГОГИЧЕСКИЙ УНИВЕРСИТЕТ ИМ. АБАЯ

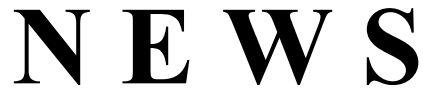

OF THE NATIONAL ACADEMY OF SCIENCES OF THE REPUBLIC OF KAZAKHSTAN

ABAY KAZAKH NATIONAL PEDAGOGICAL UNIVERSITY

ҚОҒАМДЫҚ ЖӘНЕ ГУМАНИТАРЛЫҚ ҒЫЛЫМДАР СЕРИЯСЫ

СЕРИЯ ОБЩЕСТВЕННЫХ И ГУМАНИТАРНЫХ НАУК

SERIES OF SOCIAL AND HUMAN SCIENCES

\author{
6 (322) \\ ҚАРАША - ЖЕЛТОҚСАН 2018 ж. \\ НОЯБРЬ - ДЕКАБРЬ 2018 Г. \\ NOVEMBER - DECEMBER 2018 \\ ИЗДАЕТСЯ С ЯНВАРЯ 1962 ГОДА \\ PUBLISHED SINCE JANUARY 1962 \\ ЖЫЛЫНА 6 РЕТ ШЫҒАДЫ \\ ВЫХОДИТ 6 РАЗ В ГОД \\ PUBLISHED 6 TIMES A YEAR
}

1962 ЖЫЛДЫҢ ҚАНТАР АЙЫНАН ШЫҒА БАСТАҒАН 
Ба с ре дактор

ҚР ҰҒА кұрметті мүшесі

Балықбаев Т.O.

Р е д а ц и я а лқ а сы:

экон. ғ. докторы, проф., ҚР ҰҒА академигі Баймұратов У.Б.; тарих ғ. докторы, проф., ҚР ҰҒА академигі Байпақов К.М.; филос. ғ.докторы, проф., ҚР ҰҒА академигі Есім Г.Е.; фил. ғ. докторы,, проф., ҚР ҰҒА академигі Қирабаев С.С.; эк. ғ. докторы, проф., ҚР ҰҒА академигі Кошанов А.К.; эк.ғ. докторы, проф., ҚР ҰҒА академигі Нәрібаев К.Н. (бас редактордың орынбасары); филос. ғ.докторы, проф., ҚР ҰҒА академигі Нысанбаев А.Н.; заң ғ. докторы, проф., ҚР ҰҒА академигі Сәбікенов С.Н.; заң ғ. докторы, проф., ҚР ҰҒА академигі Сүлейменов М.К.; эк. ғ. докторы, проф., ҚР ҰҒА академигі Сатыбалдин С.С.; тарих ғ. докторы, проф., ҚР ҰҒА академик Әбжанов Х.М.; тарих ғ. докторы, проф., ҚР ҰҒА корр. мүшесі Әбусеитова М.Х.; тарих ғ. докторы, проф., ҚР ҰҒА академик Байтанаев Б.А.; филол. ғ. докторы, проф., ҚР ҰҒА корр. мүшесі Жақып Б.А.; фил. ғ. докторы, проф., академик НАН РК Қалижанов У.К.; филол. ғ. докторы, проф., ҚР ҰҒА академик Қамзабекұлы Д.; тарих ғ. докторы, проф., ҚР ҰҒА академик Қожамжарова Д.П.; тарих ғ. докторы, проф., ҚР ҰҒА академик Койгелдиев М.К.; фил. ғ. докторы, проф., ҚР ҰҒА корр. мүшесі Кұрманбайұлы Ш.; тарих ғ. докторы, проф., ҚР ҰҒА корр. мүшесі Таймағанбетов Ж.К.; социол. ғ. докторы, проф., ҚР ҰҒА корр. мүшесі Шәукенова 3.К.; фил. ғ. докторы, проф., КР ҰҒА корр. мүшесі Дербісәлі А.; саяси. ғ. докторы, проф., Бижанов А.К., тарих ғ. докторы, проф., Кабульдинов 3.Е.; фил. ғ. докторы, проф., ҚР ҰҒА корр мүшесі Қажыбек Е.3.

\section{Р едакция ке н е с i:}

Молдова Республикасының ҰҒА академигі Белостечник Г. (Молдова); Әзірбайжан ҰҒА академигі Велиханлы Н. (Азербайджан); Тәжікстан ҰҒА академигі Назаров Т.Н. (Тәжікстан); Молдова Республикасының ҰҒА академигі Рошка А. (Молдова); Молдова Республикасының ҰҒА академигі Руснак Г. (Молдова); Әзірбайжан ҰҒА корр. мүшесі Мурадов Ш. (Әзірбайжан); Әзірбайжан ҰҒА корр. мүшесі Сафарова 3. (Әзірбайжан); э. ғ. д., проф. Василенко В.Н. (Украина); заң ғ. докт., проф. Устименко В.А. (Украина)

«Қазақстан Республикасы Ұлттық ғылым академиясының Хабарлары. Қоғамдық және гуманитарлық ғылымдар сериясы». ISSN 2224-5294

Меншіктенуші: «Қазақстан Республикасының Ұлттық ғылым академиясы» РҚБ (Алматы қ.)

Қазақстан республикасының Мәдениет пен ақпарат министрлігінің Ақпарат және мұрағат комитетінде 30.04.2010 ж. берілген № 10894-Ж мерзімдік басылым тіркеуіне қойылу туралы куәлік

Мерзімділігі: жылына 6 рет.

Тиражы: 500 дана.

Редакцияның мекенжайы: 050010, Алматы қ., Шевченко көш., 28, 219 бөл., 220, тел.: 272-13-19, 272-13-18, http://nauka-nanrk.kz. social-human.kz

(C) Қазақстан Республикасының Ұлттық ғылым академиясы, 2018

Типографияның мекенжайы: «Аруна» ЖК, Алматы қ., Муратбаева көш., 75. 
Главный редактор

Почетный член НАН РК

T.O. Балыкбаев

Р е дак ци онн а я коллег и я:

докт. экон. Н., проф., академик НАН РК У.Б. Баймуратов; докт. ист. н., проф., академик НАН РК К.М. Байпаков; докт. филос. Н., проф., академик НАН РК Г.Е. Есим; докт. фил. Н., проф., академик НАН РК С.С. Кирабаев; докт. экон. Н., проф., академик НАН РК А.К. Кошанов; докт. экон. Н., проф., академик НАН РК К.Н. Нарибаев (заместитель главного редактора); докт. филос. н., проф., академик НАН РК А.Н. Нысанбаев; докт. юр. Н., проф., академик НАН РК С.Н. Сабикенов; докт. юр. н., проф., академик НАН РК М.К. Сулейменов; докт. экон. Н., проф., академик НАН РК С.С. Сатубалдин; докт. ист. н., проф., академик НАН РК Х.М. Абжанов; докт. ист. н., проф., чл.-корр. НАН РК М.Х. Абусеитова; докт. ист. н., проф., академик НАН РК Б.А. Байтанаев; докт. фил. н., проф., чл.-корр. НАН РК Б.А. Жакып; докт. фиолол. н., проф., академик НАН РК У.К. Калижанов; докт. фил. н., проф., академик НАН РК Д. Камзабекулы; докт. ист. н., проф., академик НАН РК Д.П. Кожамжарова; докт. ист. н., проф., академик НАН РК М.К. Койгельдиев; докт. филол. н., проф., чл.-корр. НАН РК Ш. Курманбайулы; докт. ист. н., проф., чл.корр. НАН РК Ж.К. Таймаганбетов; докт. социол. н., проф., чл.-корр. НАН РК З.К. Шаукенова; д. филол. н., проф., чл.-корр. НАН РК А. Дербисали; доктор политических наук, проф., Бижанов А.К.; доктор ист. наук, проф., Кабульдинов 3.Е.; доктор филол. н., проф., член-корр. НАН РК Қажыбек Е.3.

Р е дак ци онны й с ов ет

академик НАН Республики Молдова Г. Белостечник (Молдова); академик НАН Азербайджанской Республики Н. Велиханлы (Азербайджан); академик НАН Республики Таджикистан Т.Н. Назаров (Таджикистан); академик НАН Республики Молдова А. Рошка (Молдова); академик НАН Республики Молдова Г. Руснак (Молдова); чл.-корр. НАН Азербайджанской Республики Ш. Мурадов (Азербайджан), член-корр. НАН Азербайджанской Республики 3.Сафарова (Азербайджан); д. э. н., проф. В.Н. Василенко (Украина); д.ю.н., проф. В.А. Устименко (Украина)

Известия Национальной академии наук Республики Казахстан. Серия общественных и гуманитарных наук. ISSN 2224-5294

Собственник: РОО «Национальная академия наук Республики Казахстан» (г. Алматы)

Свидетельство о постановке на учет периодического печатного издания в Комитете информации и архивов

Министерства культуры и информации Республики Казахстан № 10894-Ж, выданное 30.04.2010 г.

Периодичность 6 раз в год

Тираж: 500 экземпляров

Адрес редакции: 050010, г. Алматы, ул. Шевченко, 28, ком. 219, 220, тел. 272-13-19, 272-13-18, www:nauka-nanrk.kz / social-human.kz

(C) Национальная академия наук Республики Казахстан, 2018 г.

Адрес типографии: ИП «Аруна», г. Алматы, ул. Муратбаева, 75

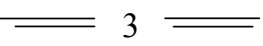


Chief Editor

\section{Honorary member of NAS RK \\ Balykbayev T.O}

Editorial board:

Doctor of economics, prof, academician of NAS RK Baimuratov U.B.; doctor of history, prof, academician of NAS RK Baipakov K.M.; doctor of philosophy, prof, academician of NAS RK Esim G.E.; doctor of philology, prof, academician of NAS RK Kirabayev S.S.; doctor of economics, prof, academician of NAS RK Koshanov A.K.; doctor of economics, prof, academician of NAS RK Naribayev K.N. (deputy editor-in-chief); doctor of philosophy, prof, academician of NAS RK Nyssanbayev A.N.; doctor of law, prof, academician of NAS RK Sabikenov S.N.; doctor of law, prof, academician of NAS RK Suleymenov M.K.; doctor of economy, prof, academician of NAS RK Satybaldin S.S.; doctor of history, prof, academician of NAS RK Abzhanov H.M; doctor of history, prof, corresponding member of NAS RK Abuseitova M.H.; doctor of history, prof, academician of NAS RK Baitanaev B.A.; doctor of philology, prof, corresponding member of NAS RK Zhakyp B.A.; doctor of philology, prof, academician of NAS RK Kalizhanov U.K.; doctor of philology, prof, academician of NAS RK Hamzabekuly D.; doctor of history, prof, academician of NAS RK Kozhamzharova D.P.; doctor of history, prof, academician of NAS RK Koigeldiev M.K.; doctor of philology, prof, corresponding member of NAS RK Kurmanbaiuly Sh.; doctor of history, prof, academician of NAS RK Taimaganbetov J.K.; doctor of sociology, prof, corresponding member of NAS RK Shaukenova Z.K.; doctor of philology, prof, corresponding member of NAS RK Derbisali A.; doctor of political science, prof Bizhanov A.K; doctor of History, prof Kabuldinov Z.E.; doctor of philology, prof, corresponding member of NAS RK Kazhybek E.Z.

\section{Editorial staff:}

Academician NAS Republic of Moldova Belostechnik.G (Moldova); Academician NAS Republic of Azerbaijan Velikhanli N. (Azerbaijan); Academician NAS Republic of Tajikistan Nazarov T.N. (Tajikistan); Academician NAS Republic of Moldova Roshka A. (Moldova) Academician NAS Republic of Moldova Rusnak G. (Moldova); Corresponding member of the NAS Republic of Azerbaijan Muradov Sh. (Azerbaijan); Corresponding member of the NAS Republic of Azerbaijan Safarova Z. (Azerbaijan); Associate professor of Economics Vasilenko V.N. (Ukraine), Associate professor of Law Ustimenko V.A. (Ukraine)

News of the National Academy of Sciences of the Republic of Kazakhstan. Series of Social and Humanities. ISSN 2224-5294

Owner: RPA "National Academy of Sciences of the Republic of Kazakhstan" (Almaty)

The certificate of registration of a periodic printed publication in the Committee of information and archives of the Ministry of culture and information of the Republic of Kazakhstan N 10894-Ж, issued 30.04.2010

Periodicity: 6 times a year

Circulation: 500 copies

Editorial address: 28, Shevchenko str., of. 219, 220, Almaty, 050010, tel. 272-13-19, 272-13-18, www:nauka-nanrk.kz / social-human.kz

(C) National Academy of Sciences of the Republic of Kazakhstan, 2018

Address of printing house: ST "Aruna", 75, Muratbayev str, Almaty 
N E W S

OF THE NATIONAL ACADEMY OF SCIENCES OF THE REPUBLIC OF KAZAKHSTAN

SERIES OF SOCIAL AND HUMAN SCIENCES

ISSN 2224-5294

Volume 6, Number 322 (2018), 176 - 184

https://doi.org/10.32014/2018.2224-5294.51

Risalat Karimova, Gulzhakhan Hajiyeva

R.B. Suleimenov Institute of Oriental Studies of the National Academy of Sciences of the Republic of Kazakhstan, Almaty, Kazakhstan, Turan University, Almaty, Kazakhstan

E-mail: risalat.karimova@mail.ru, khajieva@mail.ru

\title{
EXAMINING ETHNO-POLITICAL AND SOCIO-ECONOMIC TRANSFORMATION OF THE XINJIANG UYGHUR AUTONOMOUS REGION IN THE CONTEXT OF THE PRC NATIONAL POLICIES
}

\begin{abstract}
Politically and economically, the Xinjiang Uygur Autonomous Region holds a special significance for the PRC. Its existence not only demonstrates to the world the efficiency of China's national policy, but also ensures successful development of the country and allows for active interaction with the Central Asian countries and Russia. Consolidation of Chinese positions and its advance into Central Asia is only possible with successful development of Xinjiang as an integral part of the PRC. In this regard, China's policy on consolidating of positions in this troubled region through substantiating historical rights to sovereignty over these territories and successful state policy aimed at accelerated development of this region is of particular interest.

Formation of the multi-ethnic character of the Eastern Turkestan region (modern Xinjiang Uygur Autonomous Region of the PRC - hereinafter XUAR) is a long process, traced by scientists from the period of antiquity. This article considers the processes that have radically changed the fate of the region and turned it into a conflict zone of the present. The authors attempted to identify the internal and external causes that determine the special role of this national region for Chinese regional policies and analyze the economic and social consequences of its large-scale development. Historical, systemic, comparative (diachronic and synchronous), formal-legal methods, content analysis of publications in Uighur, Chinese, English and other languages were applied to study the modern development of the XUAR of the PRC and the role of the region in the multi-vector foreign policy of the Republic of Kazakhstan and other Central Asian countries. This allowed to identify the specifics of the region, the prerequisites for the emergence of challenges to national (Chinese), regional and international security, identify balances and imbalances of forces and threats.

Civilizational and historical approaches allowed to uncover contradictions between the culture of a conquered country and the culture of conquerors, the ineradicable striving of the local population for self-determination, and, as a consequence, to separatism, extremism and terrorism. The system-structural approach allowed to explore changes in the ethno-demographic structure of the population of the national district. In the course of the study of socioeconomic results of the accelerated modernization of the XUAR, the authors applied various techniques including diagnostic method based on the principle of consistency of goal setting, formulation of a scientific hypothesis, comprehensive study of the features and consequences of Chinese regional policy, as well as methods of economic and statistical analysis.

Key words: East Turkistan, Xinjiang, XUAR of China, national policy, separatism, regional disproportions, large-scale development, modernization.

Applicant Yao Wang, who defended thesis "Xinjiang Uygur Autonomous Region and China's Policy in the Context of Contemporary Challenges for International Security" in 2015 at the Lomonosov Moscow State University, substantiated the relevance of his theme by the fact that for the People's Republic of China the challenges posed by globalization are emerging in the Xinjiang Uygur Autonomous Region. He writes: "XUAR is one of the five autonomous regions most exposed to threats of international terrorism and religious extremism, which are also associated with manifestations of Uyghur separatism" [1, p. 3].

What are the reasons behind these challenges and threats? One of the main reasons for the Uygur separatism in the XUAR is, in our view, sinification of the region, which was implemented in a single generation. Ethnic assimilation go hand in hand with a cultural one and these factors irritate the local population.
\end{abstract}

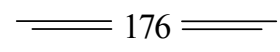


To study this situation it is necessary to look into the period of history when the risk of sinification first endangered Eastern Turkestan during the conquest by the Manchu-Chinese Ch'ing Empire in the 1760s (in this article we refer to the Eastern Turkestan as the historical and geographical region of Central Asia, corresponding to the modern XUAR of the PRC, that is, during the period of its conquest by the Qing Empire consisted of Dzungaria and Kashgariya - K.R).

Ethno-political transformation of the region. The Qing troops, having seized Dzungaria in 1757, first cleared the province eliminating almost the entire Oirat population. Researchers give horrific figures, which testify to complete devastation of the region [2, p. 462]. After that Qings initiated the reform of their own military command system in the region. The Qing governor jiangjun and three of his assistants (chief administrators) jianzan dachen were assigned to govern the region. They had several commanders of the Manchu garrisons lindui dachenei and managers banshee dachene [3, p. 164-165] in their submission. Once a foothold has been established in Dzungaria, the Qing troops began to conquer Kashgariya.

From ancient times in the conquest of new territories China has been guided by the strategy of "roasting meat in its own fat" or "ruling barbarians with the hands of barbarians", i.e., to sow a state of conflict in the enemy and solve problems with enemies hands. Preparing for expansion into Eastern Turkestan, the Qing authorities successfully achieve disengagement of the enemy forces. They isolated the Kyrgyz of Kashgar who were frightened by the bloody repressions in Dzungaria, from the Khoja and the Uighur population of the Yarkend Khanate. Some Kyrgyz feudal leaders of Kashgaria strived to establish peaceful relations with the Qing government. To this end, they sent their representatives to Beijing. As a result, the Qing authorities used some Kyrgyz feudal lords in military operations in Eastern Turkestan, which not only weakened the unity of the anti-Qing forces in the region, but also aggravated the disagreement between the Uighurs and the Kyrgyz [3, p. 169].

In 1759 the Manchu-Chinese troops, having broken down the desperate resistance of the local population, completed the seizure of Kashgariya. Part of the population, fearing reprisal, fled to Badakhshan and Kokand. Brutally cracking down the Khojas, the former rulers of the country, and the peaceful population of Kashgariya, the Qing significantly expanded the boundaries of their empire, adding a vast territory with rich natural resources.

The conquest of the conquered territory began with its colonization. Colonization was carried out by the Qing army since the mid-18th century starting from the territory of the former Dzungaria. It has expanded through building settlements and was based on different forms of land ownership, including bintuan (military settlements of Chinese soldiers), jiantun (exile settlements), citun (Manchu settlements), heitun (settlements of Uighurs sent from Kashgariya), huyetun (settlements of civil migrants from China). The state created favorable conditions for the transfer of soldiers from military service to farming, they were given land and at first provided with tax relief. Additionally, the state bought grain from Chinese farmers at favorable prices. To speed up the Chinese colonization, the authorities transferred the lands to retired soldiers and their relatives, immigrants from Chinese proper, who were heterogeneous in social status and included peasants, artisans, exiles, criminals etc. However, despite the creation of favorable conditions for settlers, provincial agriculture developed slowly [4, p. 123-124].

In 1884, the Ili district became part of the new military administrative district - Xinjiang. Xinjiang in Chinese means "New Possession" or "New Territory" [5, p. 223; 3, p. 171]. Over time, the name "Xinjiang" was entrenched over the entire Eastern Turkestan region.

The former Kashgariya was divided into a number of separate cities: 4 big (Yarkend, Kashgar, Aksu, Khotan), 4 medium (Uchturfan, Yangigisar, Kuchar, Pichan) and 23 small (Shayar, Sairam, Bai, Kurla, Yugur, etc.) cities . In the big cities, the main governors were the banshee dachens, lindui dachens or the garrison commanders were appointed as the middle ones, they were subordinated to tsantszan dachen, assistant to the Ili jianjun [3, p. 171-172].

It is important to mention that the Qing conquest has changed the ethnic composition of the region and the internal structure of Eastern Turkestan cities. In many cities there appeared a new Chinese part that lived its own life, different from the native parts of the city. Some cities were divided into three parts now including the new Manchu city. Nevertheless, for the number of objective reasons no significant changes happened in the ethnic composition of Xinjiang during the given period and up to the second half of the 20th century. 
After the conquest a powerful liberation movement of the local population began in the region. In 1760, a year after the conquest of Kashgariya, the local people's struggle against the conquerors in the former Yarkand khanate broke out again, in 1765-1767 - in Uchturfan. The number of insurgents rose up everywhere, rebellions occurred in the region one after another. The largest of them were: the uprising under the leadership of Jahangir in 1822 and 1825-1828, the uprising of seven Khojas in 1847, the rebellion led by Valikhan Tore in 1857. All these uprisings were brutally suppressed, participants executed. However, in 1864 the struggle for liberation resumed with an unprecedented scale. Kuchar was the first to rise on July 4, July 15 - Urumqi, July 17 - Manas, July 26 - Yarkand, then in August - Khotan and Turfan, in October - Komul, Barkul and Kulja, in November - Kashgar and in January 1865 Chuguchak [6, c. 13-19; 3, p. 178-190]. As a result, the Manchu-Chinese government in Xinjiang was destroyed. There emerged five independent states - Kucha, Kashgar and Khotan in Kashgariya, Urumchi and Kulja in Dzungaria. Four states, except Kulja, were subsequently united in a single state Yettishar, which existed until 1880.

The early 20th century was marked by the Uighur uprising in Kagarlyk, Yarkend and Khotan. Serious uprisings took place in Komul in 1912-1913. Another powerful Uighur uprising broke out in Komul in 1931 finally spreading to other parts of the province. In November 1933 Sabit Damolla established a short-lived "Islamic Republic of the Eastern Turkistan" in Kashgar. 1937 saw a new Uighur uprising. In 1944-1949 years there was a landmark event - the establishment of the Eastern Turkestan Republic in three districts neighboring Soviet Kazakhstan - Ili, Tarbagatay and Altai. The republic was eliminated after the arrival of the Communists in 1949.

In such extreme conditions, when the insurgent people of Xinjiang were fighting against the invaders, the Chinese population in the region could not increase significantly and over the course of two centuries it did not exceed 5-7\% [7].

An important reason for non-acceptance of the Han presence by the local population lied in civilizational differences. The local population has historically developed in the Central Asian civilizational space (under Central Asia we are considering Central Asia and Kazakhstan - K. R.). The Uighurs are ethnically and culturally linked with the peoples of Central Asia, share common historical roots. An important focus of our research is religion. Uyghurs are Muslims, due to religious differences, Chinese culture is alien and undesirable for Uighurs.

The ethno-political situation in Xinjiang began to change noticeably from the mid-twentieth century, when the region once again became a hostage to the interests of the major states of the PRC and the Soviet Union, becoming a victim of political collusion between them. Despite the pro-Soviet orientation of the local population of Xinjiang, which raised the rebellion against the Kuomintang and formed the East Turkestan Republic and participation of the National Army of the ETR in the battles against the Kuomintang, Xinjiang did not gain political independence and was included in the PRC on the rights of national autonomy. On October 1, 1955, the Xinjiang Uyghur Autonomous Republic was established.

The Communist Party of China gradually entered into force with its purpose and objectives changing in accordance with its possibilities. In particular, the CPC policy on the national issue has undergone several qualitative changes. In the formation of the concept of the national policy of the CPC, K. L. Syroezhkin defines several stages [8, p. 161-183; 9] which were generally completed by the end of the 1970s. Briefly, these changes were characterized by a gradual refusal to the national provinces of the right to self-determination and its replacement by the right to self-government. Autonomous regions were recognized as an integral part of the territory of the PRC. The main objective of the CPC in this regard is to keep the national territories within the borders of the PRC. The fourth period differs from the previous ones in that the CCP no longer needs to be camouflaged, and it is possible to openly turn to the implementation of a policy aimed at "the final elimination of any kind of national identity with complete subordination of national territories to a single centralized leadership" [8, p. 166]. Non-Han ethnic groups, in particular, the Uighurs did not want to enter the "single Chinese nation" and the national policy of socialist China became a background for the development of national separatism at a new stage of development.

The geopolitical importance of Xinjiang for China. Ethnopolitical changes in the region reflect China's state policy. As Beijing took certain political steps towards the region, the resistance of the local population increased. Change in the status of the Eastern Turkestan, increased colonization of Xinjiang by 
ethnic Han, huge gap in the standards of living between the Chinese and the indigenous population, the violation of rights of the indigenous non-Chinese population, the use of military force caused sharp discontent and aggravation of national contradictions and turned the region into a conflict zone of modernity.

Analyzing the data of the population census of $1953,1964,1982,1990,2000,2010$, it is possible to make a conclusion about the changes in the ethnic composition of the XUAR of China. It should be noted, however, that we use official data, which is tied to the purpose and objectives of China's national policy. The data of various sources are divergent in huge numbers.

It should also be taken into account that CCP deployed significant number of special paramilitary forces in the XUAR. It is still an open questions whether these units are included in the XUAR population by the censuses. Otherwise, their numbers will significantly change the data given in the tables. For example, a special unit of an administrative and territorial nature is the Xinjiang industrial and building corps, which includes many agricultural regiments, industrial, construction, transport, trade enterprises and even educational institutions. It has more than 2.2 million people, mostly Han Chinese, and only 0.3 million of these militiamen are represented by other nationalities [9, p. 120;14].

In accordance with the first census of 1953 the population of Xinjiang included: Uyghur -3 million 600 thousand people, i.e. even according to official data, they accounted for $74 \%$ of the region's population. In 2010, the latest sixth census was carried out, according to which the number of Uighurs rose up to 10001 302, Han Chinese - 8829 954, Kazakhs - 1418 273. The Hans in 2010 amounted to $40.48 \%$, but if to take into account the number pf Hui-Tzu-Dungan, the Chinese-speaking ethnic group close to the Han, then in total in 2000 their number in the XUAR have reached 8329856 people and almost equaled the number Uighurs - 8,345,622 people [10; eleven]. By 1978, by the beginning of "reform and opening up", the population of the XUAR had reached 12.3 million people, including. 5.5 million Uighurs, 5.1 million Chinese and 821 thousand Kazakhs. If to compare the changes in the ethnic composition of the province's population during 1952-1976: the number of Uighurs and Kazakhs increased almost equally by 1.6 times, and that of the Chinese by almost 16 times [14, p. 52]. Can such numbers leave indifferent the local population?

The article in the "Studies in Ethnicity and Nationalism" published by American researchers from the University of Texas in October 2017, assesses the economic effect of the Chinese "Great Leap Forward to the West" for Xinjiang. In 1999, the Chinese government launched the "Great Leap to the West" - an ambitious economic program to develop China's western border. The strategy of the "leap" was to use the growing welfare of the country to mitigate the historic ethnic tensions. However, the result of the "leap" was ambiguous: while provinces such as Xinjiang really experienced impressive economic growth, relations between Beijing and Uighurs in Xinjiang remained unchanged if not deteriorated. There are different hypotheses that explain such an outcome. In our opinion, the more appropriate to the actual situation is the hypothesis that the growing wealth primarily benefited the Han migrants. For the Uighurs, the "Great Leap to the West", despite economic growth, above all indicates continuing colonialism. The authors of the article conclude that the largest source of discontent among the Uighurs is the large-scale migration of Han population to Xinjiang. Every day thousands of ethnic Han come from the impoverished Chinese regions to Xinjiang in search of work. In 1949, Uighurs accounted for more than $75 \%$ of the total population of the region; Han people - only 7\%. Today, although the Uighurs are still the largest group in Xinjiang, they make up only about $46 \%$ of the total population [7].

The discontent of the local population of the XUAR is provoked by the state's birth control policy, which affected national minorities, whose numbers do not really affect the Chinese population, where in 2010 Han amounted to about $92 \%$ of the country's population or 1 billion 370 million people, whereas Uighurs only to $0.66 \%$.

In December 1982, family planning was enshrined in the Constitution of the PRC. In 2002, the 9th Congress of the People's Democratic Republic of China adopted the "Regulations on Population and Birth Control in the Xinjiang Uygur Autonomous Region." In Art. 15 the regulation states: spouses of Han ethnicity residing in cities can raise one child; spouses - representatives of national minorities can have up to two children; spouses of Han ethnicity who are farming can have two children; representatives of national minorities can have up to three children [15]. If we consider that Eastern Turkestan has 
historically been called a country of cities, it turns out that the local population is doomed to simple reproduction and, of course, it is impossible to overlook the discrimination of non-Han ethnic groups.

Thus, the problem of separatism, extremism and terrorism in the Eastern Turkestan existed in China from the period of the forcible annexation of the region by the Qing Empire at the end of the 18th century, which has been gradually losing its power and control over the provinces.

Socio-economic aspects of modernization of XUAR. The problem of imbalance in the level of development of the regions becomes particularly complex and acute in China, where nations and nationalities are at various stages of socioeconomic and political development, in conditions when one of nation surpasses the others in economic development, exceeds in many times their number, historically occupies dominant position in society. First of all, the western regions, especially the XUAR, are regarded as the most backward regions of the PRC, where the problems of the socioeconomic backlog are exacerbated by the ethnic factor.

So, if in the late 1980s in China out of 592 poor areas 257 (43.4\%) were western regions, then in the early 2000 s. $90 \%$ of the most backward regions were in the west of the country. Of the 80 million poor people in the country, 35 million are non-Han people. In other words, although the number of national minorities is only $8.4 \%$ of China's population, but their share among the poor is $43.75 \%$ [ $16, \mathrm{p}$. 43].

Realizing that uneven regional development can become not only an economic, but also an acute socio-political problem, the Chinese leadership has come to a decision of a radical change in the country's regional policy. Therefore, the deviation in the strategy of regional development has gradually shifted from the eastern to the western regions.

Xinjiang as a "region with a vast territory, a small population, endless natural resources and, most importantly, as a place with an important strategic significance" always attracted the attention of the Chinese authorities. (17, p. 97) However, despite the fact that the task of mastering Xinjiang was repeatedly raised, the Chinese leadership was able to approach it closely only at the beginning of the 21 st century. At the Fourth Plenum of the 15th Central Committee of the Communist Party of China on September 22, 1999, the "Strategy for the Large-scale Development of the Western Regions" was officially proclaimed.

The practical implementation of the long-term comprehensive program is designed for 50 years and includes the following main directions: socio-economic alignment of the regions, accelerated exploitation of the rich natural resources of the western regions, solution of the demographic problem of China through mass migration from demographically tense regions to the western ones, and expansion of China's geopolitical interests.

First of all, the pragmatic interest of the Chinese leadership in the XUAR is related to the prospect of using the natural resources of Xinjiang, which is mainly used outside the national autonomous region. This is due to extreme uneven distribution of oil and gas resources, a large part (about 80\%) is located in the western and central regions of the PRC.

As shown by geological exploration, in XUAR on an area of 950 thousand square meters. km there are underground layers of sedimentary rocks, promising from the point of view of the occurrence of oil. Also XUAR is the richest gas-bearing area. In recent years, the XUAR has discovered more than 30 basins, the proven oil reserves of which exceed 2 billion tons, natural gas - 700 billion cubic meters. [18, p. 61]. Therefore, currently the task of the XUAR is to expand the potential opportunities and guarantees for a stable growth in oil and gas production, the transfer of Western oil and gas resources to the East of China, and the congestion of pipelines.

In the future, the XUAR should become the "second Chinese Daqing". To achieve this goal, the Central Government annually increases funding for the exploration and development of hydrocarbon deposits in the territory of the XUAR. Credits of international financial organizations and foreign governments are also actively used. More than 120 billion yuan was invested at the initial stage of the project to supply natural gas from the western to the eastern regions [19, p. 446].

In this regard, the well-known political scientist K.L. Syroezhkin noted that the legal owners of the natural wealth of Xinjiang, according to the "Law of the PRC on the regional-national autonomy" are the local state government. However, he adds further: "... an impartial analysis shows that in the early years of its existence, as well as at present, the XUAR, despite its immense wealth, continues to" live in debt. Therefore, when the question of the so-called "looting of the natural wealth of Xinjiang" by China raises, 
in most cases it shows the desire of the local bureaucracy to secure conditions for uncontrolled possession of natural resources wealth, retaining the center's subsidies" [8, p. 215-216].

The last statement, in our opinion, is not indisputable. It is quite possible that if the autonomous region were given the opportunity, in accordance with its legally fixed status, to independently manage at least part of its natural resources and generate considerable revenues from them to raise the economy of the XUAR, then the need for subsidies for the region would disappear.

At the same time, it should be noted that the environmental system of XUAR is extremely fragile, with extremely limited environmental sustainability to external impact. Oasis is only $5 \%$ of the entire territory of the region. Intensive development of the natural resources of the XUAR can significantly worsen the environmental situation in the area. In recent years, especially since 2010, the XUAR has made great efforts to protect and restore its ecological systems, balancing the interests of economic growth and nature conservation [20, p. 4].

It is equally important for the Chinese leadership to mitigate the demographic problem in the interior and coastal provinces of the country by relocating their surplus population to a sparsely populated, by Chinese measure, XUAR. This region is the largest administrative unit among the autonomous regions of China, it occupies $1 / 6$ of the total area of the country, while its population is only $1.5 \%$ of the country's population [21, p. 79]. The justification of forced resettlement is explained by the need to professional staff, the implementation of the strategic project, and the incapability of the western regions to fulfill such grandiose tasks on their own.

It so happened that the western region is experiencing a huge shortage of qualified personnel, especially scientific and technical personnel. At the beginning of implementation of the strategy, $75 \%$ of specialists of the highest category of the country concentrated in the coastal areas, $21 \%$ in the central regions and only $4 \%$ in the western ones. In the eastern regions, out of 10,000 workers, 885 people had vocational education, while in the western regions there were only 92 . If the eastern regions had 415 higher educational establishments, in the western regions there were only 142 , most of them in the areas where they live mainly Han Chinese [22, p. 130]. Therefore, over a number of years, the deficit of specialists in the western regions is covered by their mass transfer from the eastern regions of China. Since the foundation of the XUAR before the reforms and opening up, the state through the allocation and transfer of jobs encouraged intellectuals and technical experts to go to work in Xinjiang. It invited young people, urban educated youth and workers to travel to the interior of the country to support the development of border areas and encouraged demobilized soldiers to travel to Xinjiang for permanent residence, providing them with jobs there, thus forming a generation of workers to settle in the border areas.

K. Syroezhkin, speaking of the unpreparedness of the western regions to carry out such grandiose tasks on their own, emphasizes the need to attract additional specialists from the eastern regions. At the same time, he notes that in the 1980s and 1990s, there is a tendency of reemigration of the most qualified and able-bodied personnel who arrived in the XUAR in the 1950s-1960s. The loss of such personnel is not replenished, as the new wave of migrants is represented mainly by excessive unskilled rural labor or lowskilled workers. That is, the principle of attracting qualified specialists to the western regions from the eastern and central regions, laid as one of the main ones in the strategy of "large-scale development of the West," does not yet work. In any case, with respect to Xinjiang. [23, p. 142]. In addition,"... replaced today, for example from XUAR, workers who have lived here for decades, largely mastered the local culture and traditions, tolerant of local ethnic groups "comes a new generation of cadres for whom the principle of tolerance and political expediency is of secondary importance" [24, p. 35]. These statements convincingly confirm the futility and even the negativity of such assistance.

The attraction of additional labor resources from other regions of the country can not continue indefinitely, since this has radically changed the ethnic composition of the population of the national regions, significantly increased the demographic burden on the territory of the XUAR and created the ground for ethnic conflicts. In our opinion, the more promising way to provide western regions with specialists is to raise the level of education and science at the local level, the formation of their own professional cadres from the indigenous population, and the improvement of the structure of local labor resources.

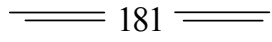


Of course, more than a decade will be required to implement a strategic plan that is aimed to reduce the gap in the level of economic development between the eastern and western regions, ensure economic prosperity, social progress and the stability of the backward regions. The achievement of this difficult task will depend, first of all, on how China will develop as a whole, whether it will be able to maintain high rates of economic growth. And most importantly, will the PRC government implement a strategic project aimed at establishing equal and mutually beneficial relations that will not only strengthen the position of highly developed regions, but also ensure adequate socio-economic and ethno-cultural development of national autonomies.

It is quite obvious that the Program for the Development of the Western Regions needs to be clarified: in clearly defining the role of the state and the powers of local governments, in adopting additional policies clarifying specific areas of work. We need a balanced approach to the decision of the labor policy, which will not violate the ethno-social balance of the autonomous regions.

\section{REFERENCES}

[1] Jao Van. Sin'czjan-Ujgurskij avtonomnyj rajon i politika KNR v kontekste sovremennyh vyzovov mezhdunarodnoj bezopasnosti. Avtoreferat dissertacii na soiskanie uchenoj stepeni kandidata politicheskih nauk. M. 2015. 30 s. (In Russian).

[2] Zlatkin I.Ja. Istorija Dzhungarskogo hanstva (1635-1758). M.: Nauka, 1964. 482 s. (In Russian).

[3] Hodzhaev A. Zahvat cinskim Kitaem Dzhungarii i Vostochnogo Turkestana. Bor'ba protiv zavoevatelej. Kitaj i sosedi v novoe i novejshee vremja. M.: Nauka, 1982. S. 153-203. (In Russian).

[4] Zaharova I. V. Material'naja kul'tura ujgurov Sovetskogo Sojuza: Sredneaziatskij jetnograficheskij sbornik. - M.: Nauka, 1959. T. 2. S. 215-258. (In Russian).

[5] Duman L.I. Agrarnaja politika cinskogo(man'chzhurskogo) pravitel'stva v Sin'czjane v konce XVIII veka. - M.-L.: Izd-vo Akademii nauk SSSR, 1936. 256 s. (In Russian).

[6] Isiev A.D. Ujgurskoe gosudarstvo Jjettishar. M.: Nauka, 1981. 92 s. (In Russian).

[7] http://centralasiaprogram.org/initiatives/uyghur-studies

[8] Syroezhkin K.L. Mify i real'nost' jetnicheskogo cepapatizma v Kitae i bezopasnost' v Central'noj Azii. Almaty: DajkPress. - 2003. - 736 s. ISBN: 9965-441-93-6 (In Russian).

[9] Syroezhkin K.L. Jevoljucija formirovanija i osnovnye cherty koncepcii nacional'noj politiki KPK. - Almaty: Kisi, 1998 (In Russian).

[10] Naselenie Kitaja po nacional'nym gruppam

$1953-2010$. https://yellow.ml/tab/ru/Naselenie Kitaja/8acebb98353f430885a3052a3f8d14fe55d7744a (In Russian).

[11] Jetnicheskij sostav naselenija provincij Kitaja. https://ru.wikipedia.org/wiki/Jetnicheskij sostav naselenija administrativnyh obrazovanij KNR (In Russian).

[12] Hess St. From the Arab Spring to the Chinese Winter: the Institutional Sources of Authoritarian Vulnerability and Resilience in Egypt, Tunisia, and China // International Political Science Review. 2013. Vol. 34, № 3. P. 254 (in Eng).

[13] Syroezhkin K.L. Kitaj: voennaja bezopasnost'. Almaty: Kazahstan. in-t strateg. issled. pri Prezidente Resp. Kazahstan, 2008. 268 s. (In Russian).

[14] Xinjiang tongji nianjian, 1998, e 57, cit. po Gel'bras V.G. Kitaj. Chem nedovol'ny ujgury. Protivorechivye itogi razvitija Sin'czjana (In Russian)

[15] Jao Van, Kapicyn V.M. // Ars administrandi. Iskusstvo upravlenija. 2013. № 3. S. 107-117. (In Russian).

[16] Dilmurat Oshur, Akram Ibragim. O masshtabnom osvoenii zapadnogo regiona i obshhem rascvete vseh nacional'nostej // Nauchnyj zhurnal Sin'czjanskogo universiteta. 2002. № 4. S. $42-47$ (In Uighur).

[17] Vostochnyj Turkestan v civilizacionnyh processah Central'noj Azii: Mat. mezhdunar. nauch. konf., posvjashhennoj pamjati K.T. Talipova (g. Almaty, Kazahstan, 23 nojabrja 2007 g.) / Otv. red.: A.K. Muminov, R.U. Karimova, A.K. Kamalov. Almaty: Mir. 2010. 456 s. ISBN: 978-601-7013-96-7 (In Russian).

[18] Matveev V.A. Jenergeticheskaja politika Kitaja: vybor novyh prioritetov // Kitaj: poisk garmonii. K 75-letiju akademika M.L. Titarenko. M.: ID «FORUM», 2009. 656 s. ISBN: 978-5-8199-0406-0 (In Russian).

[19] Preobrazovannyj Kitaj. Desjat' pjatiletnih kitajskih planov / Pod red. Jao Kajczjaija, Chjen' Junsjunja. Pekin: Kit. jekon. izd., 2002. - 486 s. ISBN: 7-5017-5543-4 (In Chinese).

[20] The State Council Information Office of the People's Republic of China. Historical Witness to Ethnic Equality, Unity and Development in Xinjiang. - Beijing: Foreign Languages Press, 2015. 56 c. (in Eng).

[21] Talipov K.T. Sin'czjan-Ujgurskij avtonomnyj rajon - glavnoe zveno v masshtabnom osvoenii zapadnyh rajonov Kitaja // Shygys. Almaty, 2004, №1. S. 76-81 (In Russian).

[22] Kalbinur Kasim. O regulirovanii kadrovoj politiki $\mathrm{v}$ hode osvoenii zapadnyh rajonov // Nauchnyj zhurnal Sin'czjanskogo universiteta. 2002. № 6. S. 130-132 ((In Uighur).

[23] Syroezhkin K.L. Problemy sovremennogo Kitaja i bezopasnost' v Central'noj Azii: Monografija. - Almaty: KISI pri Prezidente RK, 2006. - 299 s. ISBN: 9965-454-44-8 (In Russian).

[24] Syroezhkun K. Novoe puteshestvie na zapad // Kontinent, 2005. 23 fevralja - 8 marta. - S. 34-35 (In Russian). 


\section{Р.У. Каримова, Г.У. Хаджиева}

ҚР БҒМ ҒК «Р.Б.Сүлейменов атындағы Шығыстану институты», Алматы, Қазақстан, «Тұран» университеті, Алматы, Қазақстан

\section{КХР ҰЛТТЫК САЯСАТЫ КОНТЕКСІНДЕГІ ШҰАА-НЫН ЭТНОСАЯСИ ЖӘНЕ ӘЛЕУМЕТТІК-ЭКОНОМИКАЛЫК ТРАНСФОРМАЦИЯСЫ МӘСЕЛЕСІ}

Аннотация. Шыңжаң Ұйғыр автономиялық ауданы саяси және экономикалық жағынан ҚХР үшін ерекше маңызға ие. Оның болуы бүкіл әлемге тек қана Қытайдың ұлттық саясатының орнықтылығын ғана көрсетіп қана қоймай, жалпы алғанда, елдің табысты дамуы үшін, атап айтқанда, Орталық Азия және Ресей елдерімен белсенді қарым-қатынас жасау үшін қажет. Қытайдың Орталық Азияға енуі және осы бағытта өз ұстанымдарын нығайту Шыңжаңдың ҚХР-ның ажырамас бөлігі ретінде табысты дамуымен ғана мүмкін. Осыған байланысты Қытайдың бұл проблемалы аймақта өз ұстанымдарын нығайтуға, оның аумағына тарихи құқықтарын негіздеуге және оны игеруге бағытталған табысты мемлекеттік саясаты ерекше қызығушылық тудырады.

Шығыс Түркістан аймағында (қазіргі Шыңжаң Ұйғыр автономиялық ауданы - ШҰАА) полиэтникалық қоғамдың қалыптасуы - бұл ғалымдар тарапынан ежелгі дәуірден байқалатын ұзақ процесс. Ұсынылған мақалада аймақтың тағдырын түбегейлі өзгертіп, оны қазіргі заманның қақтығыс аймағына айналдырған үдерістер қаралды. Авторлар тарапынан қытайдың аймақтық саясатында зерттелетін ұлттық аймақтың ерекше рөлін анықтайтын ішкі және сыртқы себептер анықталып, оны ауқымды игерудің экономикалық және әлеуметтік салдарлары талданды. ҚХР ШҰА-ның қазіргі дамуын және аймақтың ерекшеліктерін анықтауға мүмкіндік беретін Қазақстан Республикасының және басқа да Орталық Азия елдерінің көпвекторлы сыртқы саясатындағы аймақтың ролін, қытайлықтар үшін қиындықтардың пайда болуының алғышарттарын зерттеу, халықаралық қауіпсіздік, күштер мен қауіптердің баланстары мен тепетеңсіздіктерін анықтау үшін тарихи, жүйелі, салыстырмалы (диахроникалық және синхронды), ресмиқұқықтық әдістер пайдаланылды. Өркениеттік және тарихи көзқарастар жаулапалынған ел мәдениеті мен жеңіп шыққан ел мәдениет арасындағы қайшылықты, жергілікті тұрғындардың өзін-өзі анықтауға ұмтылуына, сепаратизмге, экстремизмге және терроризмге қатысты мәселелерді айқындауға мүмкіндік береді. Жүйелік-құрылымдық тәсіл ұлттық аудан тұрғындарының этномәдени құрылымындағы өзгерістерді зерттеуге мүмкіндік берді. ШҰАА-нын жедел жетілдірудің әлеуметтік-экономикалық нәтижелерін зерттеу барысында мақсатты белгілеу принципін негізге ала отырып диагностикалық әдіс, ғылыми гипотезаны қалыптастыру, қытай аумақтық саясатының ерекшеліктері мен салдарын жан-жақты зерттеу, сондай-ақ экономикалық және статистикалық талдау әдістері пайдаланылды.

Түйін сөздер: Шығыс Түркістан, Шыңжаң, ҚХР ШҰАА, ұлттық саясат, сепаратизм, аймақтық үйлесімсіздік, ауқымды даму, жаңғырту.

УДК (323.15+338.2) (510)

\section{Р.У. Каримова, Г.У. Хаджиева}

РГКП «Институт востоковедения им. Р.Б. Сулейменова» КН МОН РК, Алматы, Казахстан, Университет «Туран», Алматы, Казахстан

\section{К ВОПРОСУ ОБ ЭТНО-ПОЛИТИЧЕСКОЙ И СОЦИАЛЬНО-ЭКОНОМИЧЕСКОЙ ТРАНСФОРМАЦИИ СУАР В КОНТЕКСТЕ НАЦИОНАЛЬНОЙ ПОЛИТИКИ КНР}

Аннотация. В политическом и экономическом плане Синьцзян-Уйгурский автономный район имеет для КНР особое значение. Его существование не только демонстрирует миру состоятельность национальной политики Китая, оно необходимо в целом для успешного развития страны, в частности, для активного взаимодействия со странами Центральной Азии, Россией. Продвижение Китая вглубь Центральной Азии, упрочение его позиций в этом направлении возможно только при успешном развитии Синьцзяна как неотъемлемой части КНР. В этой связи представляет особый интерес политика Китая, направленная на закрепление любой ценой своих позиций в этом неспокойном регионе, попытки обоснования своих исторических прав на его территорию и весьма успешная государственная политика по его освоению.

Формирование полиэтничности восточнотуркестанского региона (современный Синьцзян-Уйгурский автономный район КНР - далее СУАР) процесс длительный, прослеживаемый учеными с периода древности. 
В представленной статье рассматриваются процессы, кардинальным образом изменившие судьбу региона и превратившие его в конфликтогенную зону современности. Авторами выявлены внутренние и внешние причины, определяющие особую роль исследуемого национального района в китайской региональной политике, проанализированы экономические и социальные последствия его масштабного освоения. Для изучения современного развития СУАР КНР и роли региона в многовекторной внешней политике Республики Казахстан и других стран Центральной Азии были использованы исторический, системный, компаративный (диахронный и синхронный), формально-юридический методы, позволяющие выявить специфику региона, предпосылки возникновения вызовов национальной (китайской), региональной и международной безопасности, определить балансы и дисбалансы сил и угроз. Цивилизационный и исторический подходы дают возможность вскрыть противоречия между культурой покоренной страны и культурой завоевателей, неискоренимого стремления местного населения к самоопределению, и, как следствие, к сепаратизму, экстремизму и терроризму. Системно-структурный подход позволил изучить изменения в этно-демографической структуре населения национального района. В ходе исследования социально-экономических результатов ускоренной модернизации СУАР использованы диагностический метод, основанный на принципе последовательности постановки цели, формулировки научной гипотезы, комплексного изучения особенностей и последствий китайской региональной политики, а также методы экономическо-статистического анализа.

Ключевые слова: Восточный Туркестан, Синьцзян, СУАР КНР, национальная политика, сепаратизм, региональные диспропорции, масштабное освоение, модернизация.

\section{Information about authors:}

Karimova Risalat Usmanovna - chief Researcher, Institute of Oriental Studies. named after Ramazan B. Suleimenov SC MES RK, Professor of "Turan" University, doctor of historical Sciences, associate Professor, risalat.karimova@mail.ru;

Khajieva Gulzhahan Usmanovna - leading Researcher of the Institute of Oriental Studies named after Ramadan B. Suleimenov SC MES RK, professor of the University «Turan», Doctorate (PhD) in Economy, Associate Professor, khajieva@mail.ru 


\section{МАЗМҰНЫ}

Беспаева Р.С., Бугубаева Р.О., Мануэль Ф. Грела2. Көрсеткіштердің теңдестірілген жүйесі негізінде Щучинск-Бурабай курорттық аймағын дамытудың кешенді стратегиясын қалыптастыру ................................................................................ 5

Аюпова 3.К., Құсайынов Д.Ө.Азаматтық процесстерді жетілдірудегі интеграцияның кейбір қырлары...................... 13

Құсайынова А. А., Вальдемар Козловски, Геращенко И. П.Қазақстан республикасындағы міндетті әлеуметтік сақтандырудың қаржылық-құқықтық тетіктерінің ерекшеліктері.

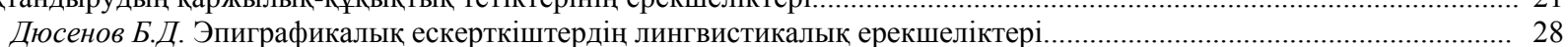

Джумадилова Ш.Г., Атабай Б.Ж. Қазақстандағы халықтың жинақтарының динамикасы......................................... 33

Карабалина А.А., Альситова А. Б., Кереймаганбетова Ж.Н., Абишева Н. М. Құндылық - рухани-адамгершілік

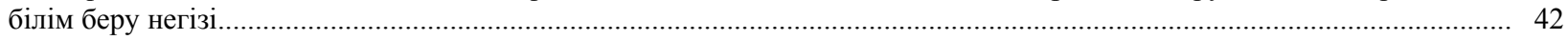

Кенжебаева Д.К., Өрмөрза Б. Ғ., Дашгин Махаммадли. Қазақстандық заманауи жастардың құндылығы............. 51

Нурманова А.Ш., Медерова Д.Е., Дюсенов Б.Д. «Бөкейхан әулетінің талдыбейіт қорымы» эпиграфикалық ескерткіштері тарихи дереккөз ретінде.

Кыдырова Ж.Ш., Онласынов Е.З., Абишова А.У., Шадиева А.А. Оңтүстік Қазақстан облысы сүт және сүт өнімдері нарығындағы жағдайды зерттеу ......

Абимова Г.У., Аманжолов Р., Мынбаева Б.Н., Ибрагимова Д.И. ЖОО-да биолог-студенттердің жобаларды

ұйымдастырылуы мен орындалуына даярлығы.......

Балтабаева А.Ю., Ризаходжаева Г. Мәдени интеграция үдерісіндегі жібек жолының феномені............................... 9

Бурганова Р.И., Абдугалина С.Е., Туякова А.Е. Студенттерге бағытталған білім беру арқылы білім сапасын

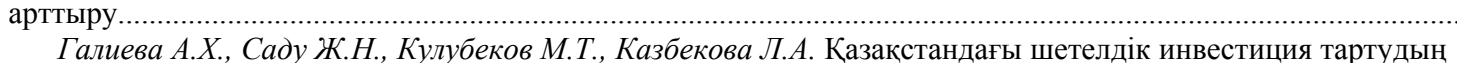

институционалдық жағдайын (талаптарын) бағалау..

Джалилов 3.Г., Батырхан Б.Ш. ХX ғ. екінші жартысындағы шетелдік исламтанушылардың ислам және саясат

туралы теориялық дискурсы.......

Джумабекова А.Т., Канатова А.Ж. Қаржылық ынтымақтастық жағдайларындағы Қазақстан республикасының

ұлттық банкінің өткізу механизмінің өзгеруі......

Дүйсен Г. М., Айтжанова Д. А. Қазақстан және Орталық Азия елдеріндегі көші-қон процесстері дамуының мәселелері мен ерекшеліктері

Есендұлова М.Н. Қазақстандағы « Қиын балаларды» оңалтудың және әлеуметтендірудің психологиялық ерекшеліктері

Жакишева К.М., Жуманова Д.Т., Мукашева Г.М. Экономиканың аграрлық секторының тұрақты дамуына арналған ауыл шаруашылық кәсіпорындарының қаржылық шарттарын мониторингінің рөлі.....

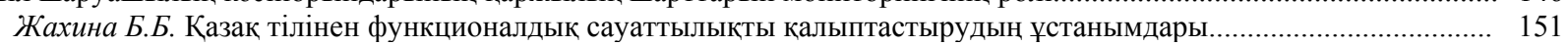

Идресова У.Х., Садуахасова 3.Ж., Муханова А.Т. Криминалистика....................................................................... 156

Савельева В. В. Қазақстандағы кредит технологиясын пайдалану және дамуының тарихи және педагогикалық базасы.

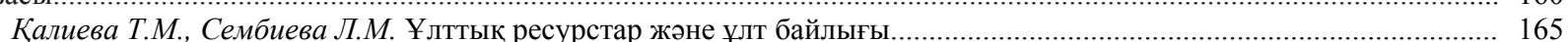

Каримова Р.У., Хаджиева Г.У. ҚХР Ұлттық саясаты контексіндегі ШҰАА-ның этносаяси және әлеуметтікэкономикалық трансформациясы мәселесі.

Керімбек Г., Молдашбаева Л., Джрауова Қ., Ажмухамедова А., Мизанова А. Қазақстан республикасының

республикалық бюджетіне түсетін салық түсімдерінің көрсеткіштерін талдау және бағалау.....

Жолдасбекова С.А., Парманкулова П.Ж., Асаналиев М.К. Мүмкіндігі шектеулі балаларды дамытудағы ұлттық ойындар

Молдакенова Е.К., Байгабулова К.К., Онаева Б.Т. БҚО-да инновациялық үрдістерді басқарудың аймақтық

аспектілігі жүйесінің дамудың жолдары.

Мұратова Г.К., Шаушенова А.Г., Жумасеитова С.Д., Онұварбаева М.Б.Білім беру үрдісінде бұлттық

технологияларын қолдану......

Несіпбеков E. Н., Аппакова Г.Н. Кәсіпорынның инвестициялық портфелін қалыптастырудың теориялық

Нургабылов М.Н., Барлыков Е.К., Егембердиева С.М. ҚР есеп өнеркәсібінің дамуының басқаруының трендсі....... 220

Нурымбетов Т.Я., Абишова А.У., Уразбаева Г.Ж., Кыдырова Ж.Ш., Байнеева П.Т., Абишо Н.У. Модернизациялық

жағдайындағы қр халқын әлеуметтік қолдауының басымдықтары.....

Рахимова С. А., Тургумбекова М. М. Қазақстан республикасындағы шағын және орта бизнестіңмемлекеттік қолдау

бағдарламалары және олардың тиімділігін жүзеге асыру шаралары.......................................................................... 233

Руденко Е.И. Орталық пен Оңтүстік Азия мемлекеттері арасындағы ұғынудың бұрмалануы - «Жұмсақ күш»

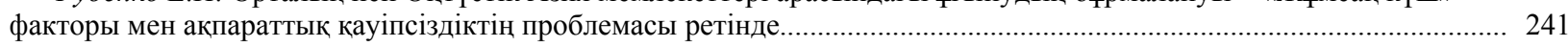

Тохтабаева Ш. Қазына-сандық.......................................................................................................... 251

Утепкалиева К.М., Сабирова Р.К., Кенбаева Г.У. Мұнай-газ секторындағы мемлекеттік-жеке серіктестікті дамыту

Мыңбаев Д. Е. Банкте басқару есебін ұйымдастыру тұжырымдамасы...

Султанова Г.С. Жаңа формацияның экономисі - бакалаврдың кәсіби құзыреттілігін қалыптастырудың

Шаяхметова А.А. Университет жағдайында инклюзивті білім беру үшін педагогтарды оқыту....... 


\section{СОДЕРЖАНИЕ}

Беспаева Р.С., Бугубаев Р.О., Мануэль Ф. Грела. Формирование комплексной стратегии развития ЩучинскоБоровской курортной зоны на основе сбалансированной системы показателей. Аюпова 3.К., Кусаинов Д.У., Уинстон Наган. Некоторые грани интеграции в совершенствовании гражданского процесса.

Кусаинова А.А., Козловски Вальдемар, Геращенко И.П. Обзор некоторых особенностей финансово-правового механизма обязательного социального страхования в республике Казахстан......

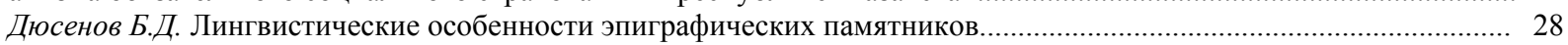

Джумадилова Ш.Г., Атабай Б.Ж.Динамика сбережений населения в Казахстане................................................... 33

Карабалина А.А., Альситова А. Б., Кереймаганбетова Ж.Н., Абишева Н. М. Ценность как базовая основа духовнонравственного образования.

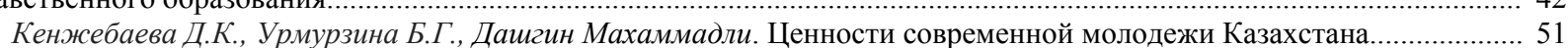

Нурманова А.Ш., Медерова Д.Е., Дюсенов Б.Д. Эпиграфические памятники «Некрополи талдыбейит династии

Бокейхановых» как исторический источник.

Кыдырова Ж.Ш., Онласынов Е.З., Абишова А.У., Шадиева А.А.Исследование ситуации на рынке молока и молочной продукции южно-казахстанской области

Абишова Г.У., Аманжолов Р., Мынбаева Б.Н., Ибрагимова Д.И. Готовность студентов-биологов к организации

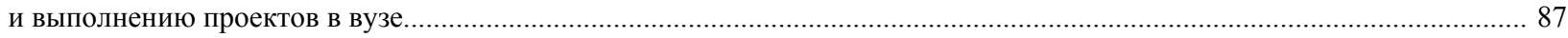

Балтабаева А.Ю., Ризаходжаева Г. Феномен великого шелкового пути в процессе культурной интеграции............... 91

Бурганова Р.И., Абдугалина С.Е., Туякова А.Е. Повышение качества образования посредством

студентоцентрированного обучения...

Галиева А.Х., Саду Ж.Н., Кулубеков М.Т., Казбекова Л.А. Оценка институциональных условий привлечения

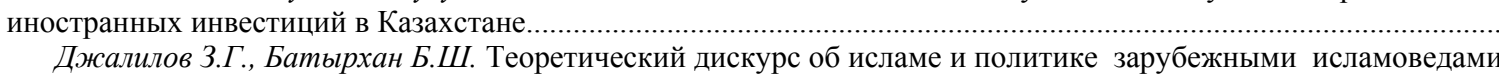
второй половины ХX в.

Джумабекова А.Т., Канатова А.Ж. Трансформация трансмиссионного механизма национального банка республики

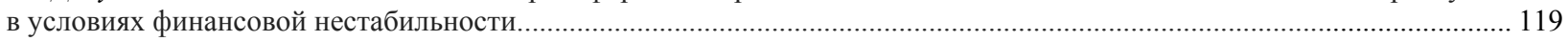

Дуйсен Г.М., Айтжанова Д.А. Проблемы и особенности развития миграционных процессов в Казахстане

и странах Центральной Азии.

Есенгулова М.Н. Психологические особенности реабилитации и социализации "Трудных подростков"

в Казахстане".

Жакишева К.М., Жуманова Д.Т., Мукашева Г.М.Роль мониторинга финансового состояния сельскохозяйственных

предприятий в обеспечении устойчивого развития аграрного сектора экономики.........................................................146

Жахина Б.Б. Принципы формирования функциональной грамотности казахского языка.......................................... 151

Идресова У.Х., Садуахасова 3.Ж., Муханова А.Т. Криминалистика......................................................................... 156

Савельева B.B. Исторические и педагогические основы формирования и разработки кредитной технологии

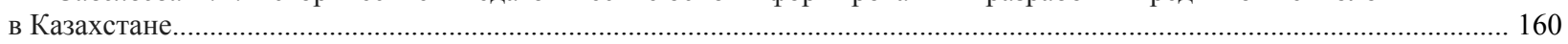

Калиева Т.М., Сембиева Л.М. Национальные ресурсы и богатство нации.................................................. 165

Каримова Р.У., Хаджиева Г.У. К вопросу об этно-политической и социально-экономической трансформации

СУАР в контексте национальной политики КНР

Керимбек Г., Молдашбаева Л., Джрауова Қ., Ажмухамедова А., Мизанова А. Анализ и оценка показателей

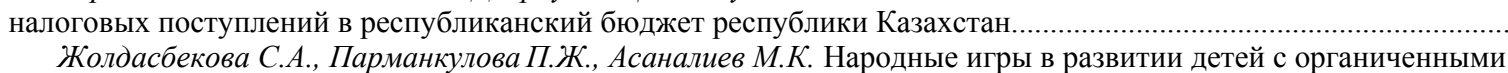

Жолдасбекова С.А., Парманкулова П.Ж., Асаналиев М.К. Народные игры в развитии детей с органиченными

Молдакенова Е.К., Байгабулова К.К., Онаева Б.Т.Пути развития системы регионального аспекта управления

инновационными процессами в АПК.

Муратова Г.К., Шаушенова А.Г., Жумасеитова С.Д., Онгарбаева М.Б. Применение облачных технологий

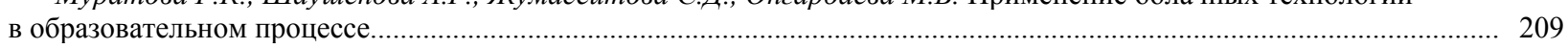

Несипбеков Е.Н., Аппакова Г.Н. Теоретические аспекты формирования инвестиционного портфеля предприятия. 214

Нургабылов М.Н., Барлыков Е.К., Егембердиева С.M. Тенденции управления развитием мясоперерабаты-

вающей отрасли в РК.

Нурымбетов Т.Я., Абишова А.У., Уразбаева Г.Ж., Кыдырова Ж.Ш., Байнеева П.Т., Абишов Н.У. Приоритеты

социальной поддержки населения РК в условиях модернизации................................................................................. 22

Рахимова С. А., Тургумбекова М. М. Программы государственной поддержки мсб в республике Казахстан и меры

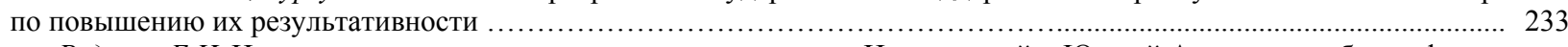

Руденко Е.И. Искаженность восприятия между государствами Центральной и Южной Азии как проблема фактора

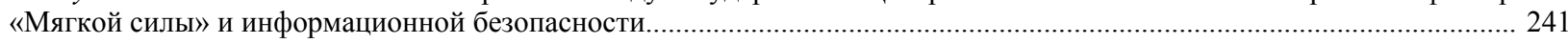

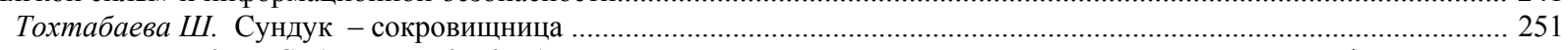

Утепкалиева К.М., Сабирова Р.К., Кенбаева Г.У.Развитие государственно-частного партнерства в нефтегазовой

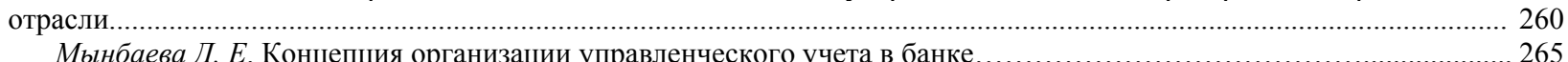

Мынбаева Д. Е. Концепция организации управленческого учета в банке...........................................2.
Султанова Г.С. Педагогические аспекты формирования профессиональных компетенций бакалавра - экономиста

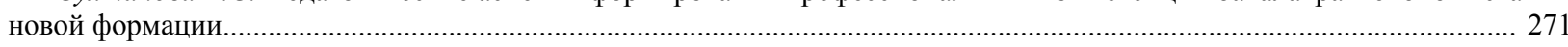

Шаяхметова А.А. О подготовке педагогических кадров к инклюзивному образованию в условиях вуза................ 277 


\section{CONTENTS}

Bespayeva R.S., Bugubayeva R.O., Manuel F. Grela. Formation of the complex strategy for development of the Schuchinsk-

Burabay resort area based on the balanced system of indicators.

Ayupova Z.K., Kussainov D.U., Winston Nagan. Some facets of integration in themodernization ofthe civil process..............13

Kussainova A.A., Kozlowski Waldemar, Gerashchenko I.P. The review of some features of the financial legal mechanism of obligatory social insurance in the republic of Kazakhstan...

Dyussenov B.D. Linguistic features of epigraphic monuments................................................................................ 28

Jumadilova Sh.G., Atabay B.Zh. Dynamics of the population savings in Kazakhstan.......................................................... 33

Karabalina A.A., Alsitova A.B., Kereimaganbetova Zh.N., Abisheva N.M. The values as critical factor of moral education... 42

Kenzhebayeva D.K., Urmurzina B.G., Dashqin Mahammadli. The modern youth values in Kazakhstan............................. 51

Nurmanova A.S., Mederova D.E., Dyussenov B.D. "Bokeykhanov dynasty taldybeyit necropolis" epigraphic monuments

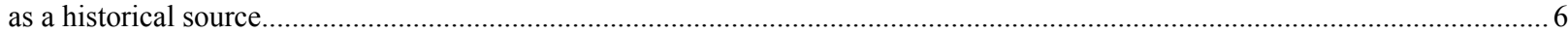

Kydyrova Zh.Sh., Onlasynov E.Z., Abishova A.U., Shadieva A.A.Research of the situation in the market of milk and dairy

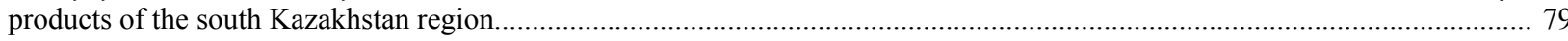

Abishova G.U., Amanzholov R.A., Mynbayeva B.N., Ibragimova D.I. Readiness of students-biologists for the organization

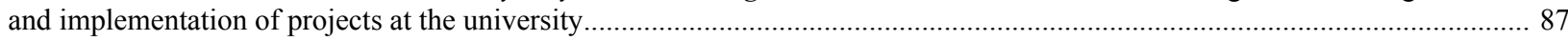

Baltabayeva A.Y., Rizakhojayeva $G$. The phenomenon of the great silk road in the cultural integration process................... 91

Burganova R.I., Abdugalina S.E., Tuyakova A.E. Improving the quality of education through student-centered education... 102

Galiyeva A.Kh., Sadu Zh.N., Kulubekov M.T., Kazbekova L.A. Assessment of the institutional terms of the foreign

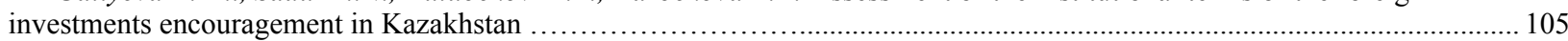

Dzhalilov Z.G. Theoretical discourse on islam and politics in foreign humanism of the second half of 20th century.......... 112

Dzhumabekova A.T., Kanatova A.ZH. Transformation of the transmission mechanism of the national bank of the republic

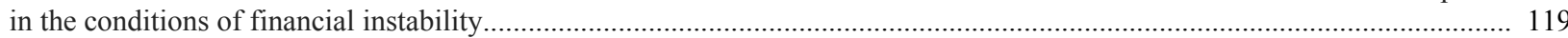

Suleimenov R.B. Problems and features of the development of migration processes in Kazakhstan and Central Asia.......... 124

Yesengulova M.N. Psychological aspects of reintegration and resocialization of "Trouble" adolescents in Kazakhstan....... 134

Zhakisheva K.M., Zhumanova D.T., Mukasheva G.M.The role of monitoring the financial condition of agricultural

enterprises in ensuring sustainable development of the agrarian sector of the economy......................................................... 146

Zhakhina B.B. Principles of functional literacy formation of the kazakh language....................................................... 151

Idresova U.Kh., Saduahasova Z.Zh., Mukhanova A.T. Criminalistics............................................................................. 156

Savelyeva $V . V$. Historicalandpedagogical bases of formation and development of credit technology in Kazakhstan........... 160

Kaliyeva T.M., Sembiyeva L.M. National Resources and national wealth.................................................................. 165

Karimova R., Hajiyeva G. Examining ethno-political and SOCIO-economic transformation of the xinjiang uyghur

autonomous region in the context of the PRC national policies........................................................................................ 176

Kerimbek G., Moldashbayeva L., Jrauova K., Azhmukhamedova A., Misanova A. Analysis and evaluation of reduction

of tax recovery of the republic of kazakhstan on the budget of the republic of Kazakhstan................................................. 185

Zholdasbekova S.A., Parmankulova P.Zh., Assanaliyev M.K. Folk games in the education of children with physical, mental and sensory disturbances..

Moldakenova E.K., Baygabulova K.K., Onaeva B.T. Ways of development of the system of the regional aspect of managing innovative processes in the APC.

Muratova G.K., Shaushenova A.G., Zhumassseitova C.D., Ongarbayeva M.B. Application of cloud technologies in the educational process......

Nurgabylov M.N., Barlikov E.K., Egemberdieva S.M. Trends of management of the development of meat processing industry in RK

Nurymbetov T.Ya., Abishova A.U., Urazbaeva G.Zh., Kydyrova Z.Sh., Baineeva P.T., Abishov N.U. Priorities of social support of the population of republic of Kazakhstan in the conditions of modernization........

Rakhimova S. A., Turgumbekova M. M. Programs of government support for sme in the republic of Kazakhstan and measures to enhance their efficiency.....

Rudenko Ye.I. Misperception between the states of Central and South Asia as a 'Soft power' and information security issue...

Tokhtabayeva Sh. Zh. Treasure-chest.

Utepkalieva K.M., Sabirova R.K., Kenbaeva G.U.Development of public private partnership approach in oil and gas

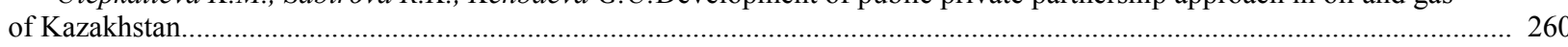

Mynbayeva D.E. Concept of organization of management accounting in bank ........................................................... 265

Sultanova G. S. Pedagogical aspects of formation of professional competence of the bachelor-economist of the new formation

Shayakhmetova A.A. On the training of teaching staff for inclusive education under the conditions of higher education institution. 


\section{PUBLICATION ETHICS AND PUBLICATION MALPRACTICE IN THE JOURNALS OF THE NATIONAL ACADEMY OF SCIENCES OF THE REPUBLIC OF KAZAKHSTAN}

For information on Ethics in publishing and Ethical guidelines for journal publication see http://www.elsevier.com/publishingethics and http://www.elsevier.com/journal-authors/ethics.

Submission of an article to the National Academy of Sciences of the Republic of Kazakhstan implies that the work described has not been published previously (except in the form of an abstract or as part of a published lecture or academic thesis or as an electronic preprint, see $\mathrm{http} / / / \mathrm{www} . e l s e v i e r . c o m / p o s t i n g p o l i c y)$, that it is not under consideration for publication elsewhere, that its publication is approved by all authors and tacitly or explicitly by the responsible authorities where the work was carried out, and that, if accepted, it will not be published elsewhere in the same form, in English or in any other language, including electronically without the written consent of the copyrightholder. In particular, translations into English of papers already published in another language are not accepted.

No other forms of scientific misconduct are allowed, such as plagiarism, falsification, fraudulent data, incorrect interpretation of other works, incorrect citations, etc. The National Academy of Sciences of the Republic of Kazakhstan follows the Code of Conduct of the Committee on Publication Ethics (COPE), and follows the COPE Flowcharts for Resolving Cases of Suspected Misconduct (http://publicationethics.org/files/u2/New_Code.pdf). To verify originality, your article may be checked by the originality detection service Cross Check http://www.elsevier.com/editors/plagdetect.

The authors are obliged to participate in peer review process and be ready to provide corrections, clarifications, retractions and apologies when needed. All authors of a paper should have significantly contributed to the research.

The reviewers should provide objective judgments and should point out relevant published works which are not yet cited. Reviewed articles should be treated confidentially. The reviewers will be chosen in such a way that there is no conflict of interests with respect to the research, the authors and/or the research funders.

The editors have complete responsibility and authority to reject or accept a paper, and they will only accept a paper when reasonably certain. They will preserve anonymity of reviewers and promote publication of corrections, clarifications, retractions and apologies when needed. The acceptance of a paper automatically implies the copyright transfer to the National Academy of sciences of the Republic of Kazakhstan.

The Editorial Board of the National Academy of sciences of the Republic of Kazakhstan will monitor and safeguard publishing ethics. 
Правила оформления статьи для публикации в журнале смотреть на сайте:

\section{www:nauka-nanrk.kz}

\section{social-human.kz}

Редакторы М.С. Ахметова, Т.А. Апендиев, Д.С. Аленов

Верстка на компьютере А.М. Кульгинбаевой

Подписано в печать 08.12.2018

Формат 60x881/8. Бумага офсетная. Печать - ризограф.

17,7 п.л. Тираж 500. Заказ 6.

Национальная академия наук $Р К$

050010, Алматы, ул. Шевченко, 28, т. 272-13-18, 272-13-19 